\title{
Simvastatin Inhibited the Growth of Gastric Cancer Cells
}

\author{
Yang CHENG-QIAN ${ }^{1}$, Wei XIN-JING ${ }^{2}$,Wei-XINBING ${ }^{3}$, Gao ZHUANG-LEI ${ }^{1}$, Zhao HONG-PENG ${ }^{1}$, \\ Xu SONGDE ${ }^{4}$, Wang PEI-LIN ${ }^{1}$
}

\author{
${ }^{1}$ The Second Hospital of Shandong University, Department of General Surgery \\ ${ }^{2}$ Shandong Provincial Hospital, Department of Dermatology \\ ${ }^{3}$ Medicine of Shandong University, Department of Pharmacology \\ ${ }^{4}$ Medicine of Shandong University, Department of Biochemistry, Jina, CHINA
}

\begin{abstract}
Statins are cholesterol-lowering drugs with multiple activities including anti-cancer effects. The objectives of this study were to examine the effects of simvastatin on gastric cancer cells in vivo. The mice models for gastric cancer cells SGC7901 were divided into two groups, control and experimental group. Simvastatin was administered orally to the experimental group, while saline given to the control group. We measured the volume and weight of tumors, and calculated RTV (relative tumor volume), T/C (relative added value of tumor) and the inhibition rate. The data was compared using t test ( $p<0.05$ was considered as statistically siginificant). Then the expression levels of PCNA, VEGF and Survivin in gastric cancer tissues were examined immunohistochemically. Our results showed that the volumes of tumors of the mice in control and experimental group were $1.943 \pm 0.500 \mathrm{~cm}^{3}, 1.227 \pm 0.623 \mathrm{~cm}^{3}$ respectively $(p<0.05)$, while RTV was $28.833 \pm 5.988$ $\mathrm{cm}^{3}, 18.842 \pm 7.401 \mathrm{~cm}^{3}$ respectively $(\mathrm{p}<0.01)$. T/C, an indication of anti-tumor, was $65.35 \%$. The weights of tumors of the mice in control and experimental group were $1.820 \pm 0.550 \mathrm{~g}, 1.320 \pm 0.500 \mathrm{~g}$ respectively $(\mathrm{p}<0.05)$. The inhibition rate was $27.47 \%$. The weight of mice in two groups had no significant differences. The PCNA index in the simvastatin group was $41.32 \pm 8.24 \%$, while in the control group was $89.25 \pm 7.69 \%$. The PCNA, VEGF and Survivin index of simvastatin group was much lower $(p<0.01)$. We concluded that simvastatin inhibited the growth of gastric cancer cells.
\end{abstract}

Keywords: Simvastatin, Gastric cancer, PCNA, VEGF, Survivin

\section{ÖZET}

\section{Simvastatin Gastrik Kanser Hücrelerini İnhibe Etti}

Statininler, kolesterol düşürücü etkilerinin yanı sıra anti-kanser gibi birçok etkiye sahiptirler. Bu çalışmanın amacı simvastatin'in kanser hücreleri üzerine etkisinin in vivo olarak araştırımasıdır. Mide kanseri için modellenmiş fareler (SGC7901), kontrol ve deneysel grup olarak ikiye ayrıldı. Deney grubuna simvastatin oral olarak verilirken, kontrol grubuna serum fizyolojik uygulandı. Tümör volümü, ağırlığı, RTV (relatif Tümör volümü), T/C (relatif toplam tümör değeri) ve inhibisyon oranı ölçüldü. Veriler t-testi kullanılarak karşılaştırma yapıldı ( $p<0.05$ altında olan değerler istatistiksel olarak anlamlı kabul edildi). Mide dokusunda PCNA, VEGF ve Survivin'in immün-histokimyasal ekspresyon seviyeleri incelendi. Sonuçlarda kontrol kolu ve deneysel kolda tümör volümü sırası ile $1.943 \pm 0.500 \mathrm{~cm} 3$ ve $1.227 \pm 0.623 \mathrm{~cm} 3$ idi $(p<$ 0.05). RTV ise kontrol kolunda ve deneysel kolda sırası ile $28.833 \pm 5.988 \mathrm{~cm} 3$ ve $18.842 \pm 7.401 \mathrm{~cm} 3$ idi $(p<0.01)$. Antitümör indikasyonu (T/C) \%65.35 idi. Kontrol ve deneysel kolda tümör ağırlıkları sırası ile $1.820 \pm 0.550$ gr ve $1.320 \pm 0.500 \mathrm{gr}$ idi ( $p<0.05)$. İnhibisyon oranı ise \%27.47 idi. İki gruptaki farelerin ağılıkları arasında istatistiksel bir fark yoktu. Simvastatin grubunda PCNA indeksi \%41.32 \pm 8.24 iken kontrol grubunda bu oran \%89.25 7.69 idi. PCNA, VEGF ve Survivin indeksi simvastatin grubunda belirgin olarak düşüktü (p<0.01). Sonuç olarak simvastatin'in gastrik kanser hücrelerini inhibe ettiği sonucuna vardık.

Anahtar Kelimeler: Simvastatin, Mide kanseri, PCNA, VEGF, Survivin 


\section{INTRODUCTION}

In recent years, increasing attentions had been paid to the relationship of cholesterol and cancer. Studies had found that malignant tumors required large amount of cholesterol to proliferate, and the level of cholesterol was lower than normal people in patients suffering with malignant tumor. Simvastatin was an effective cholesterol-lowing drug by inhibiting HMG-CoA reductase. Giving animal models of gastric cancer simvastatin, we investigated whether the growth of gastric cancer cells was inhibited.

\section{MATERIALS AND METHODS}

Simvastatin was purchased from Jingxin pharmaceutical Co., Ltd in Zhejiang, and was dissolved in saline when used.

Cell culture: The gastric cancer cells SGC7901 in the logarithmic phase, supplied by NANJING KEYGEN BIOTECH Co., Ltd were prepared into suspension that contained $1 \times 10^{7}$ cells per ml under sterile conditions. Female BALB/c mice (age: 4-5 weeks; weight: $12-15 \mathrm{~g}$ ) were purchased from Nanjing Keygen Biotech Co., Ltd.

The gastric cancer cells SGC7901 $\left(1 * 10^{7}\right.$ cells in 1 $\mathrm{ml})$ were injected subcutaneously into the right axillary of the female BALB/c mice. After 8 days, when the tumors grew to $50-75 \mathrm{~mm}^{3}$, the mice were randomly divided into two groups comprising 8 mice each. Saline $(0.4 \mathrm{ml} / \mathrm{kg} / \mathrm{d})$ was administered orally to the first group once a day for 19 days using $20 \mathrm{~mm}$ feeding needles, which was defined as the control group, whereas simvastatin $(200 \mathrm{mg} / \mathrm{kg} / \mathrm{d})$ was administered to the experimental group once a day for 19 days.

We measured the length and width of tumors with calipers in the two groups once a day. Then TV (tumor volume), RTV(relative tumor volume), T/C(relative added value of tumor) could be calculated using the following formulas:

$\mathrm{TV}=1 / 2 \times \mathrm{a} \times \mathrm{b}^{2}$

a: the length of tumor; $b$ : the width of tumor

$$
\mathrm{RTV}=\mathrm{V}_{\mathrm{t}} / \mathrm{V}_{0}
$$

$\mathrm{V}_{\mathrm{t}}$ : the volume measured once a day;

$\mathrm{V}_{0}$ : the volume when the mice were grouped.

$\mathrm{T} / \mathrm{C}(\%)=\mathrm{TRTV} / \mathrm{CRTV}_{\mathrm{RT}} \times 100$

TRTV: RTV of experimental group; CRTV: RTV of control group
Immunohistochemistry: Tissue sections were cut at $5 \mu \mathrm{m}$ from paraffin blocks. There was one section for each mouse. Dewaxing and rehydration of sections were performed according to standard procedures. The sections were placed in $3 \% \mathrm{H}_{2} \mathrm{O}_{2}$ for $10 \mathrm{~min}$ to inhibit the endogenous peroxide activity, washed three times with phosphate-buffered saline (PBS) buffer for $5 \mathrm{~min}$ and placed in normal horse serum as blocking antibody at room temperature for $30 \mathrm{~min}$. The primary antibody anti-PCNA (Proliferating Cell Nuclear Antigen) (clone PC10, Abcam, United States, 1: 100) was used. After incubation at $4^{0} \mathrm{C}$ for $24 \mathrm{~h}$, then incubation for 2 hours at $37^{\circ} \mathrm{C}$, sections were washed three times with PBS buffer for 5 min. Biotinylated anti-mouse immunoglobulin was used as the second antibody. After incubation at $37^{\circ} \mathrm{C}$ for $30 \mathrm{~min}$, sections were washed three times with PBS buffer for 5 min. After incubation with the S-A/ HRP at $37^{\circ} \mathrm{C}$ for $30 \mathrm{~min}$, sections were washed with PBS buffer for 5 min. Coloration with 3,3-diaminobenzidin (DAB), kept at room temperature without light for $10 \mathrm{~min}$, finished with the distilled water. The sections were counterstained with hematoxylin. Three high power fields were randomly selected for each tissue section. PCNA index was determined by the percentage of the cells positively stained that was tan or brown by PCNA in the nucleus.

The VEGF (vascular endothelial growth factor) index and Survivin(also called baculoviral inhibitor of apoptosis repeat-containing 5 or BIRC5) index were obtained by the same method.

Statistical analysis: The volume, weight and PCNA, VEGF, Survivin index of tumors in control and experimental groups were compared using $t$ test. $\mathrm{P}<$ 0.05 was considered as statistically significant.

\section{RESULTS}

Simvastatin reduced the volume of gastric cancer. After 17 days, the volume of tumors of the mice in control and experimental group was $1.943 \pm 0.500 \mathrm{~cm}^{3}$, $1.227 \pm 0.623 \mathrm{~cm}^{3}$ respectively ( $<<0.05$ ), while RTV was $28.833 \pm 5.988 \mathrm{~cm}^{3}, 18.842 \pm 7.401 \mathrm{~cm}^{3}$ respectively $(\mathrm{p}<0.01)$. T/C, an indication of anti-tumor, was $65.35 \%$.

Simvastatin reduced the weight of gastric cancer.The weights of tumors of the mice in control and experimental group were $1.820 \pm 0.550 \mathrm{~g}, 1.320 \pm 0.500 \mathrm{~g}$ re- 
International Journal of Hematology and Oncology

\begin{tabular}{|c|c|c|c|c|c|c|}
\hline Groups & Animals & $\begin{array}{l}\text { Initial volume } \\
\text { tumors } \mathrm{cm}^{3}\end{array}$ & $\begin{array}{l}\text { Terminal volume } \\
\text { tumors } \mathrm{cm}^{3}\end{array}$ & RTV & $\begin{array}{l}\text { Terminal weight } \\
\text { of mice }(\mathrm{g})\end{array}$ & $\begin{array}{l}\text { Weight of } \\
\text { tumors (g) }\end{array}$ \\
\hline Simvastatin & 8 & $0.064 \pm 0.007$ & $1.227 \pm 0.623^{\star}$ & $18.842 \pm 7.401^{\star \star}$ & $19.1 \pm 1.6$ & $1.32 \pm 0.50^{\star}$ \\
\hline Control & 8 & $0.067 \pm 0.009$ & $1.943 \pm 0.500$ & $28.833 \pm 5.988$ & $20.0 \pm 0.9$ & $1.82 \pm 0.55$ \\
\hline \multicolumn{7}{|c|}{$\begin{array}{l}\text { Data represent } X \pm S D, n=8 \\
{ }^{*} p<0.05 ;{ }^{* *} p<0.01 \\
\text { After } 17 \text { days, the volume and weight of tumors in simvastatin group was smaller than the control group, and the difference was significant }(p<0.05) \\
\text { so was RTV }(p<0.01)\end{array}$} \\
\hline
\end{tabular}
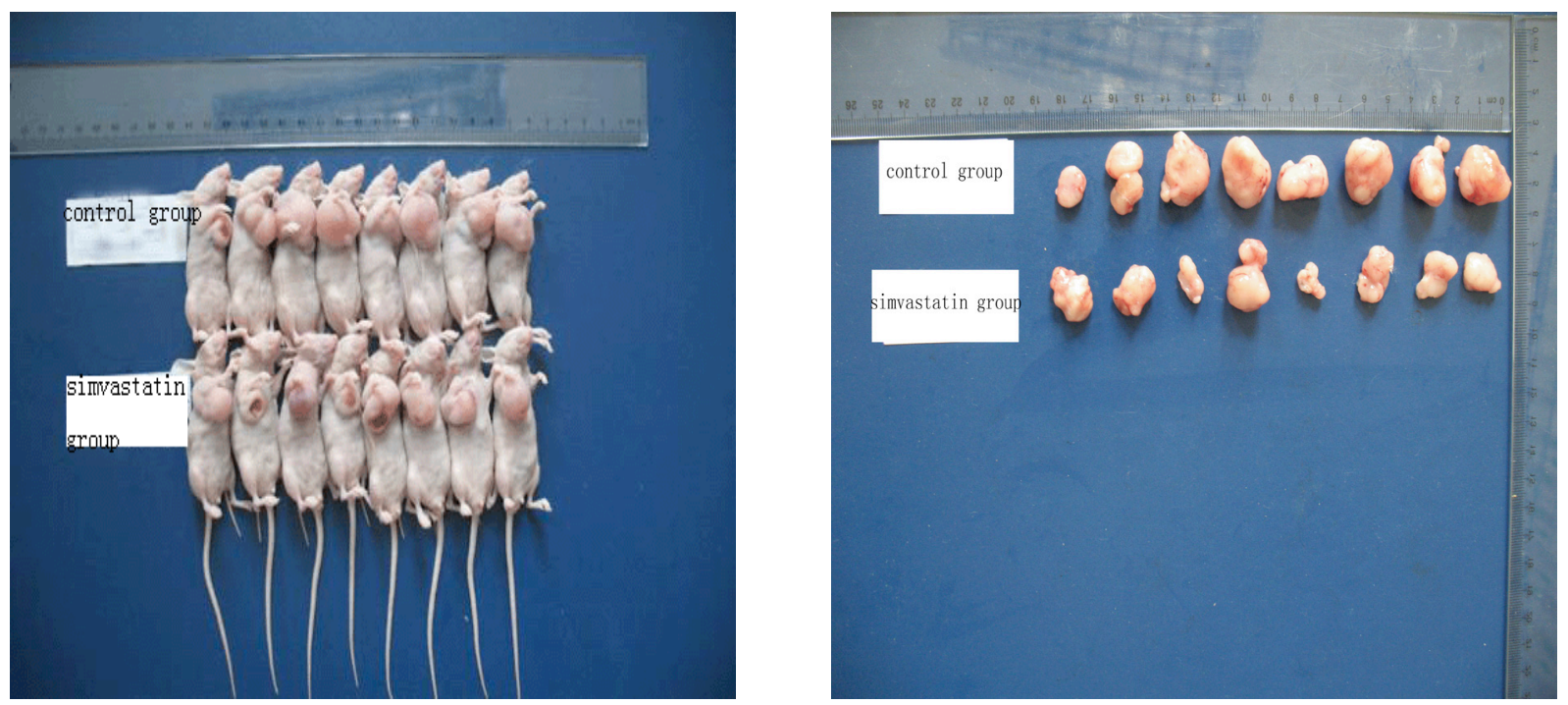

Figure 1. The tumors peeled off the mice of control group and experimental group

spectively $(\mathrm{p}<0.05)$. The inhibition rate was $27.47 \%$. There were no significant differences in the mice weight between two groups. The PCNA, VEGF and Survivin index in the simvastatin group was $32.35 \pm 6.43 \%, 28.26 \pm 4.23 \%$ and $23.96 \pm 3.87 \%$, while in the control group was $91.24 \pm 6.59 \%, 89.35 \pm 3.28 \%$ and $90.35 \pm 5.64 \%$. The PCNA, VEGF and Survivin index of simvastatin group were much lower $(\mathrm{p}<$ $0.01)$.

\section{DISCUSSION}

Despite a temporal decrease in the incidence rates, gastric cancer remains a major clinical burden. It is the fourth most common human malignant cancers in the world, with more than 900,000 new cases diagnosed every year and the second common case of cancer related death, about 700,000 die from gastric cancer. ${ }^{1}$ Looking for a new therapy for gastric cancer is very important for human. In recent years, researches about relationship of cholesterol and gastric cancer were popular. Studies found that the level of cholesterol was significantly lower in cancer-suffering patients than normal people, and was related to the course and prognosis of the disease. ${ }^{2}$ Studies also found in some tumors, such as human myeloid leukemia, endometrial cancer, choriocarcinoma, liver cancer, colon cancer and breast cancer, levels of serum cholesterol were lower than normal people. ${ }^{3-7}$ In our past studies, we also found the similar results in gastric cancer. ${ }^{8,9}$ When the level of cholesterol was reduced, the growth of cancer cells may be inhibited.

Cholesterol was essential for the membrane-integrity and biological functions of cells, and was precursors 

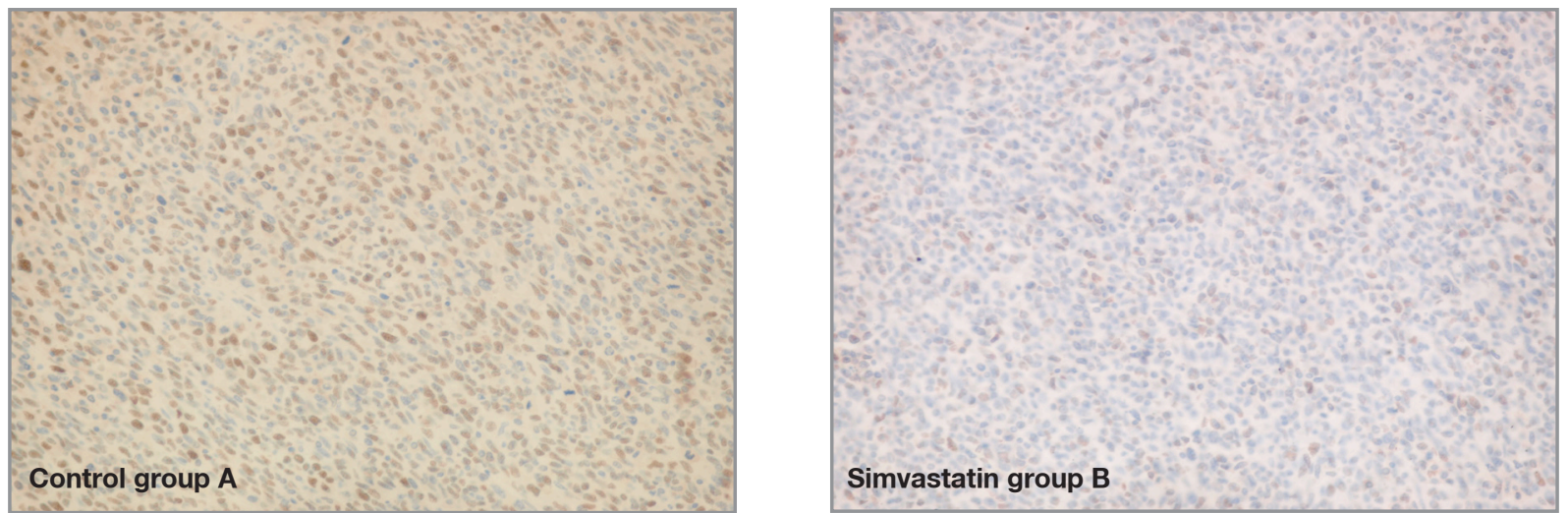

Figure 2. PCNA staining shows that positive tumor cells in control group(A) are much more than in the simvastatin group(B).(400x, DAB served as chromogen)
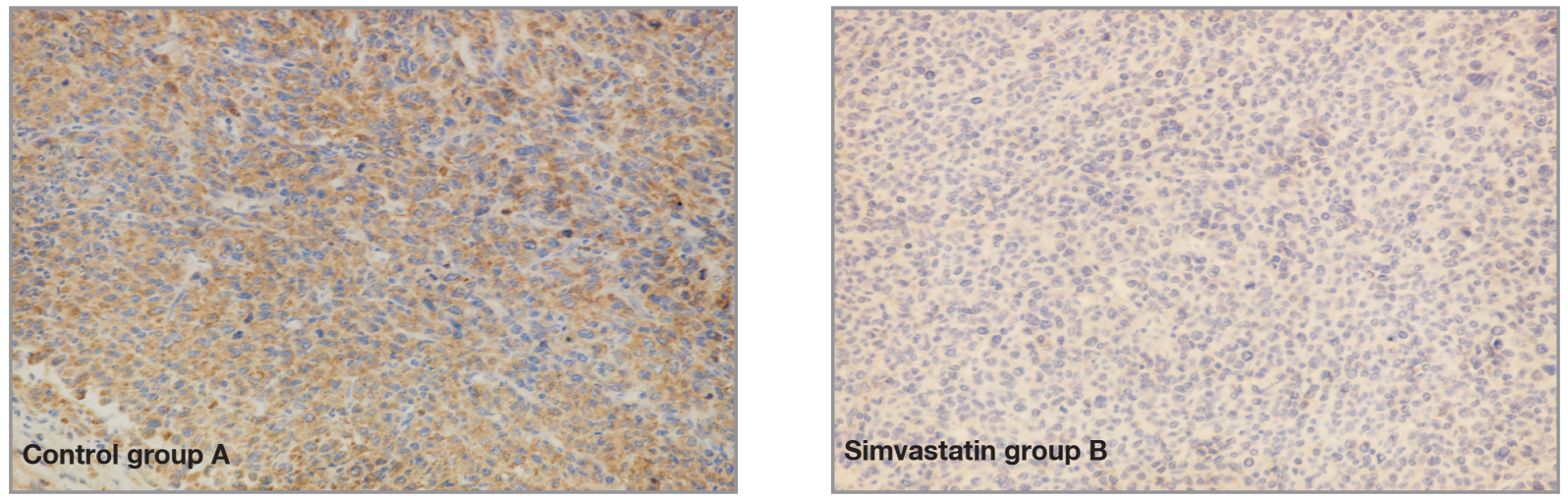

Figure 3. VEGF staining shows that positive tumor cells in control group (A) are much more than in the simvastatin group (B).(400x, DAB served as chromogen)
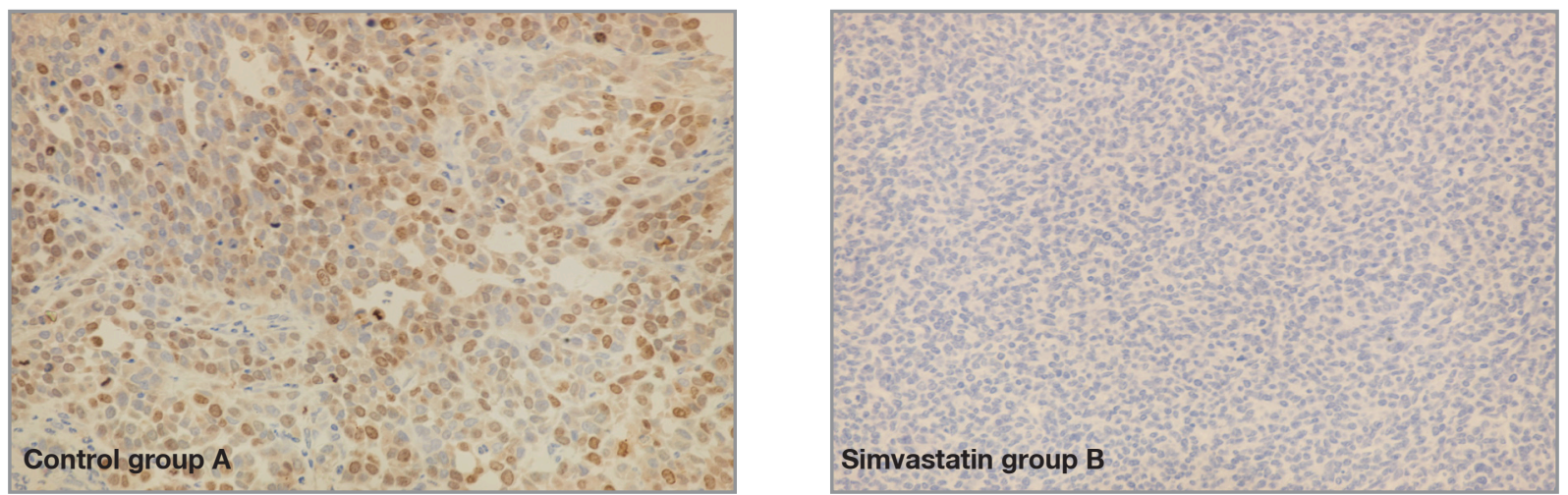

Figure 4. Survivin staining shows that positive tumor cells in control group (A) are much more than in the simvastatin group (B). (400x, DAB served as chromogen)

of several physiological-active substances. Cholesterol was synthesized by the mevalonate pathway, for which HMG-CoA reductase (3-hydroxy-9-methylglutaryl coenzyme A reductase) was a rate-limiting enzyme. By inhibiting HMG-CoA reductase, statins had been proven anti-tumor effects both in vitro and in vivo in multiple tumor types, such as breast cancer $^{10}$, lymphoma ${ }^{11}$, colorectal cancer ${ }^{12}$, melanoma ${ }^{13}$.
The mechanism might be that synthesis of lipid isoprenoid intermediates, including FPP (farnesyl pyrophosphate) and GGPP (geranylgeranyl pyrophosphate), was inhibited. FPP activated the Ras GTPase family while GGPP activated the Rho/Rac family, they were essential for tumor's growth. Cao et al. ${ }^{14}$ found that atorvastatin inhibited hepatocellular carcinoma initiation and growth by blocking both MYC 
phosphorylation and activation. Follet et al. ${ }^{15}$ found that lovastatin strongly suppressed expression of genes (p21) involved in cell division, and the inhibition was enhanced when docetaxel used together.

In the experiment, after the mice were given simvastatin for 17 days, the volume and weight of gastric tumors in experimental group were smaller than the control group, and the differences were statistically significant. Because lack of sufficient cholesterol for growth, cancer cells in experimental group growed more slowly. On the other hand, the weight of mice in two groups had no significant differences which showed that cholesterol was extremely important to cancer cells and simvastatin had little influence on the growth of normal cells, that made the drug's antitumor effect more specifically.

The proliferating cell nucleus antigen (PCNA), a $36 \mathrm{KDa}$ molecular weight protein, played an important role in DNA synthesis as a cofactor of polymerase $\delta$. The level of PCNA could reflect proliferation of gastric cancer cells. ${ }^{16}$ As the decreased apoptotic cells and the increased proliferating cells were obviously related to the tumor genesis and tumor progression in gastric carcinoma, so the index of PCNA could be used as a prognostic factor in advanced gastric cancer. ${ }^{17}$ In the study, we could see that the PCNA index in the simvastatin group was obviously lower than the control group. As PCNA index reflected the proliferation of gastric cancer cells, so the proliferation of cancer cells in simvastatin group was inhibited obviously.

Angiogenesis, the growth of new blood vessels, was an important aspect of tumorigenesis that not only provided tumor cells with nutrients and oxygen, but additionally served as a pathway for tumor cells to enter the circulatory system, where subsequent metastasis may occur. ${ }^{18}$ VEGF, a glycoprotein with a molecular weight of 34-46 kDa, was the most potent and essential as regulator of angiogenesis. Increased VEGF expression has been measured in most human tumors. ${ }^{19}$ In gastric cancer, VEGF expression is related to tumor aggressiveness and is ultimately an indicator for poor prognosis. ${ }^{20-22}$ In the study, we could see that simvastatin inhibited the level of VEGF in gastric cancer cells.

Survivin, as a newly identified bifunctional protein, suppressed cell apoptosis and regulated cell division. Based on the previously published studies, reactivation of survivin expression had been demonstrated in gastric cancer.$^{23,24}$ The high expression rate in metastatic lesions in gastric cancer suggested a possible role of survivin in cancer invasiveness and metastasis. ${ }^{25}$ In the study, we could see that simvastatin inhibited the level of survivin in gastric cancer cells

We found simvastatin inhibited the growth of gastric cancer cells in vivo in this animal experiment. But the mechanism, VEGF and survivin may play an important role, was unclear that would be the focus of our study in future.

\section{Acknowlegdments:}

We appreciated that the research was supported by Scientific and technological projects of Shandong Province (Project No. 031050119).

\section{REFERENCES}

1. Fox JG, Wang TC. Inflammation, atrophy, and gastric cancer. J Clin Invest 117: 60-69, 2007.

2. Tomiki Y, Suda S, Tanaka M, et al. Reduced low-densitylipoprotein cholesterol causing low serum cholesterol levels in gastrointestinal cancer: a case control study. J Exp Clin Res 23: 233-240, 2006.

3. Fiorenza AM, Branchi A, Sommariva D. Serum lipoprotein profile in patients with cancer. A comparison with non-cancer subjects. Int J Clin Lab Res 30: 141-145, 2000.

4. Jiang J, Nisson-Ehle P, Ning XY. Influence of liver cancer on lipid and lipoprotein metabolism. Lipid Health Dis 5: 4, 2000.

5 Yang $\mathrm{HH}$, Chen XF, Hu W, et al. Lipoprotein(a) level and its association with tumor stage in male patients with primary lung cancer. Clin Chem Lab Med 47: 452-457, 2009.

6 Vitols S, Björkholm M, Gahrton G, et al. Hypocholesterolemia in malignancy due to elevated low density lipoprotein receptor activity in tumor cells: evidence from studies in patients with leukemia. Lancet 2: 1150-1154, 1985.

$7 \quad$ Hynds SA, Welsh J, Stewart JM, et al. Low density lipoprotein metabolism in mice with soft tissue tu-mors. Biochim Biophys Acta 795: 589-595, 1984

8 Zhen G, Chun-xiang W, Pei-lin W, et al. Correlation among pathology grouping, serum cholesterol and LDL in patients with gastric cancer. Journal of Shandong University 45: 160162, 2007

9 Pei-lin W, Chunxiang W, Wenbing Y, et al. The primary study on the relationship between LDL receptor and differentiated degree of gastric adenocarcinoma. Chin J Curr Adv Gen Surg 7: 215-216, 2004. 
International Journal of Hematology and Oncology

10 McKenney JM. New cholesterol guidelines, new treatment challenges. Pharmaco-therapy 22: 853-863, 2002.

11 Maehara $\mathrm{Y}$, Emi $\mathrm{Y}$, Baba $\mathrm{H}$, et al. Recurrences and related characteristics of gastric cancer. Br J Cancer 74: 975-979, 1996.

12 Elpek GO, Gelen T, Aksoy NH, et al. Microvessel count, proliferating cell nuclear antigen and $\mathrm{Ki}-67$ indices in gastric adenocarcinoma. Pathol Oncol Res 6: 59-64, 2000.

13. Folkman J. Angiogenesis. Annu Rev Med 57 :1-18, 2006.

14. Ferrara N, Davis-Smyth T. The biology of vascular endothelial growth factor. Endocr Rev 18: 4-25, 1997.

15. Song ZJ, Gong P, Wu YE. Relationship between the expression of iNOS, VEGF, tumor angiogenesis and gastric cancer. World J Gastroenterol 8: 591-595, 2002.

16. Lieto E, Ferraraccio F, Orditura M, et al. Expression of vascular endothelial growth factor (VEGF) and epidermal growth factor receptor (EGFR) is an independent prognostic indicator of worse outcome in gastric cancer patients. Ann Surg Oncol 15: 69-79, 2008.

17. Suzuki S, Dobashi Y, Hatakeyama Y, et al. Clinicopathological significance of platelet-derived growth factor (PDGF)-B and vascular endothelial growth factor-A expression, PDGF receptor-beta phosphorylation, and microvessel density in gastric cancer. BMC Cancer 10: 659, 2010.
18. Zhu XD, Lin GJ, Qian LP, Chen ZQ. Expression of survivin in human gastric carcinoma and gastric carcinoma model of rats. World J Gastroenterol 9: 1435-1438, 2003.

19. Yu J, Leung WK, Ebert MPA, et al. Increased expression of survivin in gastric cancer patients and in first degree relatives. Br J Cancer 87: 91-97, 2002.

20. Wang ZN, Xu HM, Jiang L, et al. Expression of survivin in primary and metastatic gastric cancer cells obtained by laser capture microdissection. World J Gastroenterol 10: 30943098, 2004

\section{Correspondence}

Yang CHENG-QIAN, M.D.

The Second Hospital of Shandong University

Department of General Surgery

250033 Jina / CHINA

e-mail: ycqdanbo@yahoo.com.cn 